\title{
French Parliamentary Documents
}

$M r$. Roberts is a reference librarian, Service to Readers Unit, and Mrs. Wojewodski is a member of the professional staff, Acquisition Unit, United Nations Library.

$\mathrm{T}$ HIS essay deals with the documents issued at the present time by the two chambers of the French Parliament, the Assemblée Nationale and the Conseil de la République. Some notes on the documents of the two consultative organs, the Conseil Economique and the Assemblée de l'Union Française, have also been added. Before describing the documents themselves a brief statement of the functions of these bodies, as provided by the Constitution of 27 October 1946, may be helpful. The adoption of this Constitution did not, however, lead to many changes in the form of publication of parliamentary documents. Many of the series described in this essay have long histories.

The Assemblée Nationale is elected directly and it alone has the power of finally approving proposed legislation. The Conseil de la République renders advisory opinions on bills approved by the Assemblée Nationale. If the Conseil de la République reports that it is in disagreement with the proposals of the Assemblee Nationale, the latter body must again examine the bill. The Assemblée Nationale then decides finally whether or not the bill shall become

\footnotetext{
* The substance of this paper is based on information given us while we were in Paris during the Sixth General Assembly of the United Nations (Nov. I95IFeb. 1952) by M. Luca of the Service de Legislation Etrangere of the Assemblee Nationale and by M. Andre Roussy, Librarian of the Conseil de la Republique. Both these gentlemen were most helpful to us in this and other matters. They are not, however, responsible for any errors that this paper might contain. We have also drawn freely on other writings on the subject. Some of these are mentioned at the end of this article.
}

law. If an absolute majority of the sénateurs in the Conseil de la République approved a bill differing from the one passed in the Assemblée Nationale, a similar majority is necessary at the second reading in the Assemblée Nationale for the bill to pass. The Conseil Economique may examine all bills of an economic and social character (excluding the budget) and others which the Assemblée Nationale may submit to it. The Assemblée de l'Union Française advises on bills and proposals sent to it by the Assemblée Nationale, the French Government or the Governments of the associated states. It can also submit proposals relating to the overseas territories to the French Government.

The most convenient way of describing the French parliamentary documents seems to be the illogical one of analyzing the contents of the Journal officiel de la République Francaise. The Journal officiel is not itself a parliamentary publication but an administrative one. It does, however, include many parliamentary documents; moreover, of the publications described in this essay, it is probably the one best known in Englishspeaking countries. It is published daily and one may subscribe separately to certain of its constituent parts.

It has four principal parts, the first of which is entitled Lois et décrets, arrêtés, circulaires, avis, communications, informations et annonces. This part includes all the laws approved by the Assemblée $\mathrm{Na}$ tionale and also decrees, orders, etc. made by the executive branch of the government. It may be said to include all the legal texts of general interest concerning metropolitan France and some texts concerning the over- 
seas territories of the French Union. There are, however, some arrétés and circulaires which are not included. This part of the Journal officiel has monthly and annual subject indexes. A chronological table follows each subject index. This includes references to laws, decrees, etc. "of general interest" only; enactments concerning individuals have to be sought in the subject index. This Lois et décrets part also includes, from time to time, special supplements, such as those listing persons who have obtained military and other medals.

French laws are also collected into a series of volumes entitled Recueil des lois; these are printed on the presses of the Assemblée Nationale. The laws are printed in chronological order, with information about the parliamentary documents issued concerning the enactments when they were in the bill stage. The annexes to some laws are not included in these volumes. They have chronological tables and an annual subject index is included, on colored paper, in the volume containing the laws for the latter part of each year. There is also a subject index in the volume completing the laws approved by the first legislature of the Assemblée Nationale, i.e. covering the period January I95I-June I95I. The décrets and arrétés are not cumulated into volumes and the Journal officiel remains the best general source for finding their texts, although many of them also appear in the publications of the various ministries and elsewhere.

The second part of the Journal officiel is entitled Débats parlementaires. This contains the official records of the proceedings of the Assemblée Nationale, the Conseil de la République and the Assemblée de l'Union Française. The three sections are in separately paginated fascicules. Debates appear in the Journal officiel on the day following that of the séance concerned and, naturally, this section only appears when the assemblies are in session. The texts of the debates as recorded in Débats parlementaires are established by the official stenographers and in certain cases they have been submitted to the deputés or sénateurs before printing; they are verbatim texts. Each of the three sections has an annual index of names. There is a combined annual subject index for the Assemblée $\mathrm{Na}$ tionale and the Conseil de la République, while the Assemblée de l'Union Française has its own subject index.

Prior to their appearance in the Journal officiel the debates in the Assemblée $\mathrm{Na-}$ tionale and the Conseil de la République have been recorded in two series of Comptes rendus analytiques officiels. These records are prepared by special "Services des Comptes Rendus Analytiques Officiels" and they are printed on the presses of the respective assemblies. They are made available to all deputés, sénateurs and accredited journalists at great speed. Sheets are also posted in the lobbies as soon as they are ready. These Comptes rendus are, on the average, about two-thirds of the length of the verbatim report; they are not official texts. Those of the Assemblée Nationale are mimeographed, while those of the Conseil de la République are printed; neither series has an index.

The texts of the debates as published in the Débats parlementaires section of the Journal officiel appear, after a considerable delay, in three series of volumes, one for each assembly, entitled Annales-débats. The pagination remains the same; the $A n$ nales-débats are, however, printed on better paper, they have more detailed indexes by speaker and subject (in separate volumes) and they are sewn into paper covers. They are usually large volumes which need to be bound promptly by libraries that intend to keep them permanently. Libraries may feel able to discard the Débats parlementaires section of the Journal officiel when the equivalent section 
of Annales-débats is on their shelves. Written questions and, later, the questions and their answers, if they are obtained, are included in Débats parlementaires. 'They have separate annual indexes, one for each assembly. In these indexes the questions are grouped according to the government departments responsible for answering them. They subsequently appear in $A n$ nales-débats. The Assemblée Nationale has collected the written questions posed during the second half of 1949 into a separate volume of Questions écrites ( $195 \mathrm{I}$ ) ; it is not certain whether the series will be continued.

The third part of the Journal officiel is entitled Documents parlementaires; it contains the texts of bills, reports, etc. introduced in the three assemblies. At the end of the year separate chronological tables for the documents of each assembly are published. Before appearing together in the various fascicules of Documents parlementaires each item is published separately as an Impression. Some Impressions are single sheets of an ephemeral nature, while others, such as certain bills and their annexes and certain reports of commissions, are volumes of considerable importance. The word Impression does not appear on the documents themselves; it is, however, the name generally applied to them. The annexes to the bills setting out the budget proposals are not reprinted in the Documents parlementaires; they do, however, appear as annexes to Impressions.

The Impressions are numbered quartos, the numbers of the Assemblee Nationale commencing at one at the beginning of each legislature, while those of the Conseil de la République begin afresh each year. The numbers are allocated in advance. Some proposals are withdrawn before they have actually been introduced; in such cases the Impression will merely have the allotted number and the name of the sponsor. Such an Impression is called a carton; cartons never appear in the Documents parlementaires, which explains some gaps in the numbers in that publication. Moreover, the Impressions do not always appear in Documents parlementaires in an exact numerical order.

Some typical headings found on Impressions will now be described. A projet de loi is a bill introduced by the government, while a proposition de lo $i$ is a bill introduced by a member of an assembly. Bills are sent for examination to committees (commissions); these committees issue rapports. If more than one committee is involved, the other committees may issue avis. It can be decided that a bill be sent back to a commission for further study or perhaps for the coordination of the original text with the amendments that have been proposed. Such a procedure may give rise to a further series of rapports, avis, etc. Résolutions are decisions on procedural matters, suggestions addressed to the government, or the expression of an assembly's sentiments on important national or international events; they do not have the force of law. Thus some of the Impressions are headed Proposition de résolution.

The Conseil de la République and the Assemblée de l'Union Française publish annual summary indexes of their Impressions.

Amendements presented are mimeographed and distributed before the debates; they are not numbered in the Impressions series. Most Impressions are printed on the presses of the assembly concerned. There are, however, some budget documents which are printed elsewhere, as well as some Impressions which appear in mimeographed form.

We have noted that the Débats parlementaires section of the Journal officiel is republished in series entitled Annalesdébats. In the same way the Documents parlementaires section is republished in three 
series of Annales-documents, after some delay. Those of the Conseil de la République and the Assemblée de l'Union Française include indexes with names and subjects in the one alphabet. The Assemblée Nationale publishes indexes to both its Annalesdébats and its Annales-documents at the end of each legislature, with the title Tables des archives. Legislatures are elected for five years and the Tables des archives for the legislature that completed its term in June I95I are expected to appear during 1952.

Before returning to the Journal officiel to describe its fourth part, we may note here some separate series of parliamentary documents which may be included under the general term Impressions but which do not appear in the principal numbered series of quarto Impressions just described and which, for the most part, are not reprinted in the Journal officiel. First, there are the feuilletons of the assemblies. These are octavo-size leaflets which are published daily when the assemblies are sitting. They contain the order of the day and a list of the Impressions distributed on that day. The Bulletin des commissions gives in a very abbreviated form a report of the work of the parliamentary committees. Then there are some octavo-size Impressions which give the texts of bills adopted by the Assemble Nationale and the texts of avis issued by the Conseil de la République.

Returning now to the Journal officiel, its fourth part consists of what may be termed auxiliary documents (documents para-parlementaires). These consist of the Avis et rapports of the Conseil Economique, with their annual index. The most important of these reports and advices are reprinted in pamphlet form in. a series entitled Etudes et travaux which is published by Presses Universitaires de France. Etudes et travaux, emanating as they do from a private publisher, are not considered parlia- mentary publications by French librarians. The Bulletin du Conseil Economique contains the reports of the debates in that body. It is a separate publication, though it is printed by the Imprimerie des Journaux Officiels and looks like a part of the Journal officiel. From time to time the latter publication also includes Annexes administratives; these are mostly reports on a variety of topics emanating from government departments.

The various assemblies also publish works containing their rules of procedure, their lists of members, etc. These additional items will not be described here.

The two current bibliographies of French Government publications that we have, the fortnightly Bibliographie sélective des publications officielles françaises (a joint publication of the Comite de Coordination pour la Documentation des Sciences Sociales and the Commission Interministerielle de Documentation et Diffusion) and Supplément $F$ of Bibliographie de la France both begin with sections devoted to Lois et traités and Assemblées constitutionnelles. Here one finds recorded new volumes in the Annales series, volumes of the Recueil des lois, etc. In addition, especially important texts in the Journal officiel are listed separately in the first of the bibliographies just mentioned. The individual Impressions are only exceptionally recorded in these bibliographies.

There is an excellent account given in the preface to a catalog of French Government documents published in 1940; it describes many practices which survived the constitutional change in 1946 and which are still current today. ${ }^{1}$ Present day parlia-

\footnotetext{
1 France. Ministere de l'Instruction Publique. Inventaire general des publications officielles. 1er serie: Institutions centrales de l'etat. T. I. Publications administratives et techniques, $1937-1938$. Paris, Librairie Berger-Levrault I940, pp. Xxxvii-lv. See also Dam. pierre, J. de. Les publications officielles des pouvoirs pierre, J. de. Les publications officielles des pouvoirs
publics. I $24-130$.
}

(Continued on page 265) 
fonso XIII. Madrid, Revista de occidente, [1952] $2 \mathrm{v}$.

An alphabetical dictionary of persons, events, and subjects in the history of Spain up to the end of the reign of Alfonso XIII in I93I. Articles are generally brief, though some of the more important entries cover several pages; all are signed. Bibliographical sources, not given in the text, appear in an Indice historigráfico (v.2, p. 1493-1519), which is followed by a chronology and a number of sketch-maps. Specialists were in charge of each period or field, and were assisted by a number of collaborating scholars.

\section{Elwell-Sutton, Laurence Paul. A Guide} to Iranian Area Study. Wash., Amer. Council of Learned Societies, I952. 235p. \$4.

Compiled under the auspices of the Committee on Near Eastern Studies of the American Council of Learned Societies.

Includes survey articles on the geography, population and language, social evolution, history, administration, economic structure, religion, intellectual development, literature and arts. These are followed by a Chronology, p. I IO-I6I, and a Bibliography, p.162-235.

Ettinghausen, Richard. A Selected and Annotated Bibliography of Books and Periodicals in Western Languages Dealing with the Near and Middle East: with Special Emphasis on Modern and Medieval Times. Wash., Middle East Inst., I 952. II I p. \$I.50.

Lists 1719 western-language books, and the more important periodicals, with very brief annotations. Includes titles published through Summer 195I. Selection was made by a group of scholars and the list is intended primarily for the use of colleges and libraries.

Rosenthal, Franz. History of Muslim Historiography. Leiden, Brill, I952. 558p. \$I 2 .

A comprehensive history and discussion of historical writing among the Moslem peoples.

Rössler, Hellmuth and Franz, Günther. Biographisches Wörterbuch zur deutschen Geschichte. München, Oldenbourg, 1952- Lfg. I-3, Abbe-Hessen. (In progress). DM45 the set.

$T_{0}$ be complete in about 45 signatures (8-9 to a Lfg.): parts to appear to 2-monthly intervals. Will include some 2,000 individual biographies, in all fields and from Roman times up to 1933, mainly of Germans but also of some foreigners important in the history of Germany. Brief bibliographical notes.

p. ix-xix, index by period; p. xx-xxxi, index by field or profession (subdivided by period); p. xxxii-xlviii, index by region (subdivided by period).

Westfälische Bibliographie, hrsg. von der Historischen Kommission für Westfalen in Verbindung mit dem Verein für Geschichte und Altertumskunde Westfalens. Bearb. von Alois Bömer und Hermann Degering. Münster i. Westf., Verlag Regensberg, I952- Lfg. I-4. (Veröffentlichungen der Historischen Kommission des Provinzialinstituts für Westfälische Landes- und Volkskunde. XXIV.) (In progress).

Lfg. I-4 (Bogen I-2O), p.I-320.

Classed arrangement. An extensive bibliography of Westphalian materials including periodical articles.

\section{French Parliamentary Documents (Continued from page 258)}

mentary documents are also described in an excellent though more general, article by M. Roussier entitled "Les publications officielles du Gouvernement français." 2 In English much information about parliamentary documents has been included in a detailed study by Lidderdale. ${ }^{3}$

2 Carnegie Endowment for International Peace. European Center. Les publications officielles et la documentation internationale, ed. M. Roussier, Paris, I $952, \mathrm{pp}^{2} 3 \mathrm{I}-52$.

3 D. W. S. Lidderdale, The Parliament of France. London, The Hansard Society [195I], especially pp. I I6I $22 ;$ I 74-1 92 . 